\title{
Independent replication analysis of genetic loci with previous evidence of association with juvenile idiopathic arthritis
}

\author{
Justine A Ellis ${ }^{1 *}$, Raul A Chavez ${ }^{1}$, Angela Pezic², Anne-Louise Ponsonby², Jonathan D Akikusa ${ }^{3,4}$, \\ Roger C Allen ${ }^{3,4}$ and Jane E Munro 3,4
}

\begin{abstract}
Background: Over the last five years, there have been numerous reports of association of juvenile idiopathic arthritis with single nucleotide polymorphisms (SNPs) at various loci outside the major histocompatibility complex $(\mathrm{MHC})$ region. However, the majority of these association findings have been generated using a limited number of international cohorts, and thus there is benefit in further independent replication. To address this, we examined a total of 56 SNPs in 42 non-MHC gene regions previously reported to be associated with JIA, in the ChiLdhood Arthritis Risk factor Identification sTudY (CLARITY), a new Australian collection of cases and healthy child controls.

Findings: Genotyping was performed on a total of 324 JIA cases (mean age 9.7 years, 67.3\% female) and 568 controls (mean age 7.8 years, $40.7 \%$ female). We demonstrated clear evidence for replication of association of JIA with SNPs in or around C12orf30, C3orf1, PTPN22, STAT4, and TRAF1-C5, confirming the involvement of these loci in disease risk. Further, we generated evidence supportive of replication of association of JIA with loci containing AFF3, CD226, MBL2, PSTPIP1, and RANTES (CCL5). These results were robust to sensitivity analyses for ethnicity.

Conclusion: We have provided valuable independent data as to the underlying genetic architecture of this understudied pediatric autoimmune disease, further confirming five loci outside the $\mathrm{MHC}$, and supporting a role for a further five loci in determining disease risk.
\end{abstract}

Keywords: Juvenile idiopathic arthritis, Genetic association, Independent replication

\section{Findings}

Our understanding of the genetic basis of juvenile idiopathic arthritis (JIA) has recently increased, but still lags behind many other autoimmune diseases. This is largely due to the paucity of DNA collections internationally. While association of JIA with variation in the major histocompatibility complex (MHC) is well-established [1], over the last five years, there have been a number of reports of new JIA susceptibility loci that lie outside this region. These findings have resulted from candidate gene approaches (for example, examining genes known to be associated with rheumatoid arthritis), and more recently, from a limited number of genome-wide association study

\footnotetext{
* Correspondence: justine.ellis@mcri.edu.au

${ }^{1}$ Genes, Environment \& Complex Disease, Murdoch Childrens Research Institute, 50 Flemington Rd, Parkville, Vic 3052, Australia

Full list of author information is available at the end of the article
}

(GWAS) approaches. The vast majority of reports describe discovery and replication findings generated from two large sample collections, from the UK and the US [2]. Thus, although solid evidence for association with JIA has usually been described, for many of the identified loci, further replication in an entirely independent JIA sample would be beneficial in confirming their contribution to disease risk.

To address this, we performed a single nucleotide polymorphism (SNP) replication study within a new sample of JIA cases and healthy hospital-based child controls, collected so far as part of the ongoing Australian CLARITY study (ChiLdhood Arthritis Risk factor Identification sTudY) [3]. We selected 56 SNPs from 42 gene regions. Candidacy was based on published evidence of association, or a trend towards association, with total JIA, or one or more of its subtypes. These genes 
Table 1 Clarity SNP association results, full sample

\begin{tabular}{|c|c|c|c|c|c|c|c|c|}
\hline \multirow[b]{2}{*}{ Gene } & \multirow[b]{2}{*}{ SNP } & \multirow[b]{2}{*}{ Minor allele } & \multirow[b]{2}{*}{ Case MAF } & \multirow[b]{2}{*}{ Control MAF } & \multirow{2}{*}{$\begin{array}{l}\text { Best } \\
\text { test } p^{\S}\end{array}$} & \multicolumn{2}{|r|}{ Allelic } & \multirow{2}{*}{$\begin{array}{l}\text { Evidence fo } \\
\text { replication? }\end{array}$} \\
\hline & & & & & & $\mathbf{P}$ & OR $(95 \% \mathrm{Cl})$ & \\
\hline \multirow[t]{3}{*}{ ADAD1-IL2-IL21 } & rs17388568 [6] & A & 0.25 & 0.24 & $0.29 R$ & 0.55 & $1.07(0.85,1.36)$ & $\mathrm{N}$ \\
\hline & rs13143866 [6] & A & 0.28 & 0.26 & $0.28 \mathrm{D}$ & 0.31 & $1.12(0.90,1.40)$ & $\mathrm{N}$ \\
\hline & rs6822844 $[4,5]$ & $\mathrm{T}$ & 0.13 & 0.12 & $0.42 \mathrm{R}$ & 0.46 & $1.12(0.83,1.49)$ & $\mathrm{N}$ \\
\hline AFF3 & rs1160542 [5] & G & 0.49 & 0.46 & $0.16 \mathrm{R}$ & 0.25 & $1.12(0.92,1.36)$ & $P$ \\
\hline ANGPT1 & rs1010824 [6] & $\mathrm{T}$ & 0.17 & 0.16 & $0.71 \mathrm{D}$ & 0.82 & $1.03(0.79,1.34)$ & $\mathrm{N}$ \\
\hline ATXN2 & rs653178 [7] & G & 0.55 & 0.46 & $0.00023 \mathrm{~A}$ & 0.00023 & $1.44(1.19,1.76)$ & Y \\
\hline $\mathrm{BACH} 2$ & rs11755527 [7] & G & 0.44 & 0.46 & $0.34 \mathrm{D}$ & 0.41 & $0.92(0.76,1.12)$ & $\mathrm{N}$ \\
\hline C12orf30 & rs17696736 [6,8] & G & 0.50 & 0.41 & $0.00044 \mathrm{~T}$ & 0.0005 & $1.42(1.16,1.72)$ & Y \\
\hline C3orf1 & rs4688011 [9] & $A$ & 0.24 & 0.19 & $0.016 \mathrm{D}$ & 0.02 & $1.32(1.04,1.68)$ & Y \\
\hline CD14 & rs2569190 [11] & A & 0.48 & 0.50 & $0.24 \mathrm{R}$ & 0.43 & $0.92(0.76,1.12)$ & $\mathrm{N}$ \\
\hline CD226 & rs763361 [5] & $\mathrm{T}$ & 0.52 & 0.48 & $0.059 \mathrm{~A}$ & 0.059 & $1.21(0.99,1.47)$ & $P$ \\
\hline CLEC16A & rs6498169 [12] & G & 0.37 & 0.35 & $0.30 \mathrm{~A}$ & 0.3 & $1.11(0.91,1.36)$ & $\mathrm{N}$ \\
\hline COG6 & rs7993214 [6] & $\mathrm{T}$ & 0.30 & 0.29 & $0.41 \mathrm{~T}$ & 0.41 & $1.09(0.88,1.36)$ & $\mathrm{N}$ \\
\hline CTLA4 & rs3087243 [5] & A & 0.46 & 0.46 & $0.80 \mathrm{R}$ & 0.97 & $0.997(0.82,1.21)$ & $\mathrm{N}$ \\
\hline $\mathrm{DCN}^{*}{ }^{*}$ & rs939898 [22] & G & 0.21 & 0.18 & $0.057 \mathrm{D}$ & 0.11 & $1.22(0.95,1.56)$ & $\mathrm{N}$ \\
\hline ERAP1† & rs30187 [13] & $\mathrm{T}$ & 0.39 & 0.37 & $0.36 \mathrm{D}$ & 0.46 & $1.08(0.88,1.32)$ & $\mathrm{N}$ \\
\hline $\mathrm{FHIT}^{*}$ & rs9311745 [22] & C & 0.07 & 0.08 & $0.86 \mathrm{~A}$ & 0.86 & $0.97(0.66,1.41)$ & $N$ \\
\hline HUNK* & rs2833547 [22] & $\mathrm{T}$ & 0.25 & 0.26 & $0.46 \mathrm{D}$ & 0.66 & $0.95(0.76,1.19)$ & $\mathrm{N}$ \\
\hline IL15 & rs13139573 [9] & $\mathrm{T}$ & 0.47 & 0.43 & $0.0016 \mathrm{G}$ & 0.13 & $1.16(0.96,1.41)$ & $?$ \\
\hline \multirow[t]{2}{*}{ IL23R } & rs11209026 [13] & A & 0.07 & 0.05 & $0.22 \mathrm{~T}$ & 0.23 & $1.29(0.85,1.94)$ & $\mathrm{N}$ \\
\hline & rs11465804 [6] & G & 0.06 & 0.05 & $0.44 \mathrm{~T}$ & 0.45 & $1.18(0.77,1.80$ & $\mathrm{N}$ \\
\hline \multirow[t]{3}{*}{ IL2RA } & rs12251307 [6] & $\mathrm{T}$ & 0.11 & 0.12 & $0.34 \mathrm{~A}$ & 0.34 & $0.86(0.63,1.17)$ & $N$ \\
\hline & rs706778 [2] & A & 0.45 & 0.43 & $0.26 \mathrm{~T}$ & 0.26 & $1.12(0.92,1.36)$ & $\mathrm{N}$ \\
\hline & rs2104286 [6,14] & G & 0.21 & 0.22 & $0.21 \mathrm{R}$ & 0.63 & $0.94(0.74,1.20)$ & $\mathrm{N}$ \\
\hline IL7R & rs6897932 [5] & $\mathrm{T}$ & 0.25 & 0.23 & $0.17 \mathrm{D}$ & 0.19 & $1.16(0.93,1.46)$ & $\mathrm{N}$ \\
\hline \multirow[t]{2}{*}{ JMJD1C-REEP3 } & rs6479891 [9] & $\mathrm{T}$ & 0.17 & 0.18 & $0.44 \mathrm{D}$ & 0.64 & $0.94(0.73,1.21)$ & $\mathrm{N}$ \\
\hline & rs12411988 [9] & C & 0.16 & 0.17 & $0.47 \mathrm{R}$ & 0.74 & $0.96(0.73,1.24)$ & $N$ \\
\hline KIF5A & rs1678542 [15] & C & 0.36 & 0.39 & $0.22 \mathrm{~A}$ & 0.22 & $0.88(0.72,1.08)$ & $\mathrm{N}$ \\
\hline LPP & rs1464510 [7] & $\mathrm{T}$ & 0.46 & 0.46 & $0.81 \mathrm{R}$ & 0.93 & $1.01(0.83,1.23)$ & $N$ \\
\hline MBL2 & rs1800451 [16] & A & 0.03 & 0.02 & $0.059 \mathrm{~T}$ & 0.061 & $1.88(0.96,3.67)$ & $P$ \\
\hline MEFV & rs224204 [17] & $\mathrm{T}$ & 0.49 & 0.47 & $0.36 \mathrm{D}$ & 0.38 & $1.09(0.90,1.33)$ & $\mathrm{N}$ \\
\hline $\mathrm{NLRP} 3^{\circ}$ & rs3806265 [17] & C & 0.34 & 0.35 & $0.46 \mathrm{D}$ & 0.54 & $0.94(0.76 .1 .15)$ & N \\
\hline NOD2 & rs1861759 [17] & C & 0.39 & 0.37 & $0.26 \mathrm{D}$ & 0.64 & $1.05(0.86,1.28)$ & $\mathrm{N}$ \\
\hline NRBF2-EGR2 & rs10995450 [9] & $\mathrm{T}$ & 0.24 & 0.24 & $0.96 \mathrm{R}$ & 0.98 & $0.998(0.79,1.25)$ & $N$ \\
\hline PRKCQ & rs4750316 [15] & C & 0.17 & 0.18 & $0.33 R$ & 0.42 & $0.90(0.70,1.17)$ & $\mathrm{N}$ \\
\hline PSTPIP $1^{\circ}$ & rs4078354 [17] & $\mathrm{T}$ & 0.33 & 0.36 & $0.13 \mathrm{~A}$ & & $0.85(0.69,1.05)$ & $P$ \\
\hline \multirow[t]{3}{*}{ PTPN2 } & rs1893217 [6] & C & 0.20 & 0.18 & $0.50 \mathrm{~A}$ & 0.5 & $1.09(0.85,1.40)$ & $N$ \\
\hline & rs7234029 $[2,6]$ & G & 0.19 & 0.18 & $0.43 \mathrm{D}$ & 0.49 & $1.09(0.85,1.40)$ & $\mathrm{N}$ \\
\hline & rs2542151 [6] & G & 0.20 & 0.18 & $0.49 \mathrm{D}$ & 0.53 & $1.08(0.85,1.39)$ & $\mathrm{N}$ \\
\hline PTPN22 & rs2476601 [6,18] & A & 0.10 & 0.07 & $0.006 \mathrm{~A}$ & 0.006 & $1.62(1.15,2.30)$ & Y \\
\hline \multirow[t]{2}{*}{ RANTES (CCL5) } & rs2107538 [19] & $\mathrm{T}$ & 0.21 & 0.18 & $0.039 \mathrm{D}$ & 0.097 & $1.23(0.96,1.58)$ & $P_{\infty}$ \\
\hline & rs2280788 [19] & G & 0.02 & 0.02 & $0.30 \mathrm{~T}$ & 0.31 & $1.45(0.71,2.96)$ & $\mathrm{N}$ \\
\hline SLITRK5* & rs1074044 [22] & C & 0.44 & 0.44 & $0.81 \mathrm{D}$ & 0.9 & $1.01(0.83,1.23)$ & $\mathrm{N}$ \\
\hline
\end{tabular}


Table 1 Clarity SNP association results, full sample (Continued)

\begin{tabular}{|c|c|c|c|c|c|c|c|c|}
\hline \multirow[t]{3}{*}{ STAT4 } & rs8179673 [15] & C & 0.29 & 0.24 & $0.012 \mathrm{D}$ & 0.024 & $1.29(1.03,1.61)$ & Y \\
\hline & rs3821236 [6] & A & 0.25 & 0.21 & $0.013 \mathrm{D}$ & 0.038 & $1.28(1.01,1.61)$ & Y \\
\hline & rs7574865 $[6,8,15]$ & $\mathrm{T}$ & 0.29 & 0.24 & $0.0091 \mathrm{D}$ & 0.025 & $1.29(1.03,1.61)$ & Y \\
\hline \multirow[t]{2}{*}{ TNFAIP3 } & rs6920220 [8,15] & A & 0.22 & 0.20 & $0.29 \mathrm{~A}$ & 0.29 & $1.14(0.90,1.44)$ & $\mathrm{N}$ \\
\hline & rs13207033 [15] & A & 0.26 & 0.29 & $0.26 \mathrm{D}$ & 0.29 & $0.89(0.71,1.11)$ & $\mathrm{N}$ \\
\hline \multirow[t]{2}{*}{ TRAF1-C5 } & rs2900180 [15] & $\mathrm{T}$ & 0.37 & 0.32 & $0.014 R$ & 0.046 & $1.23(1.00,1.51)$ & Y \\
\hline & rs3761847 [21] & A & 0.42 & 0.40 & $0.32 \mathrm{~A}$ & 0.32 & $1.11(0.90,1.36)$ & $\mathrm{N}$ \\
\hline VTCN1 & rs12046117 [22] & $\mathrm{T}$ & 0.17 & 0.15 & $0.33 \mathrm{~A}$ & 0.33 & $1.14(0.87,1.49)$ & $\mathrm{N}$ \\
\hline
\end{tabular}

* No gene attribution in original publication, closest gene by UCSC Genome Browser listed.

+ Associated specifically with enthesitis related JIA in original report.

${ }^{0}$ Associated specifically with psoriatic JIA in original report.

$\S$ Model providing most significant $P$ value: $A=$ allelic, $G=$ genotypic, $T=$ Cochrane Armitage Trend Test (additive), $D=$ dominant, $R=$ recessive.

\# Evidence for replication $Y=$ Yes, $P=$ Partial, $N=$ No. See text for definitions. ?= potential for $A / T$ allele reversal with respect to the prior report.

$\infty$ Finding listed as $\mathrm{P}$ (partially replicated) since for this SNP, prior evidence was for a non-significant trend towards association in a direction consistent with our own.

included ADAD1-IL2-IL21 [4-6], AFF3 [5], ANGPT1 [6], ATXN2 [7], BACH2 [7], c12orf30 [6,8], c3orf1 [9], CCR5 [10], CD14 [11], CD226 [5], CD247 [2], CLEC16A [12], COG6 [6], CTLA4 [5], ERAP1 [13], IL12A [7], IL15 [9], IL23R [6,13], IL2RA [2,6,14], IL7R [5], JMJD1C-REEP3 [9], KIF5A [15], LPP [7], MBL2 [16], MEFV [17], NLRP3 [17], NOD2 [17], NRBF2-EGR2 [9], PRKCQ [15], PSTPIP1 [17], PTPN2[2,6], PTPN22 [6,18], RANTES (CCL5) [19], STAT4 [6,8,15], TNFA [20], TNFAIP3 [8,15], TRAF1-C5 [15,21], and VTCN1 [22]. Additional SNPs from four other loci not attributed to any gene in the original publication but lying closest to the genes $D C N 1$, FHIT, HUNK, and SLITRK5 [22] were also selected. Genotyping was performed on a total of 324 JIA cases (mean age 9.7 years, $67.3 \%$ female) and 568 controls (mean age 7.8 years, $40.7 \%$ female) using the Sequenom MassARRAY system (assay design details available from the authors). After quality control pruning (removal of SNPs with Hardy Weinberg Equilibrium $\mathrm{p}<0.01$, and SNPs or samples with $<90 \%$ genotyping success rate) genotypes were successfully generated for 51 SNPs at 38 gene loci in 318 cases and 556 controls. SNPs excluded from analysis are listed in Additional file 1. Allelic, genotypic, additive (Cochrane-Armitage test for trend), dominant and recessive association analyses were performed using PLINK v1.07 [23]. Given the a priori evidence for association of each SNP, no adjustments for multiple testing were made.

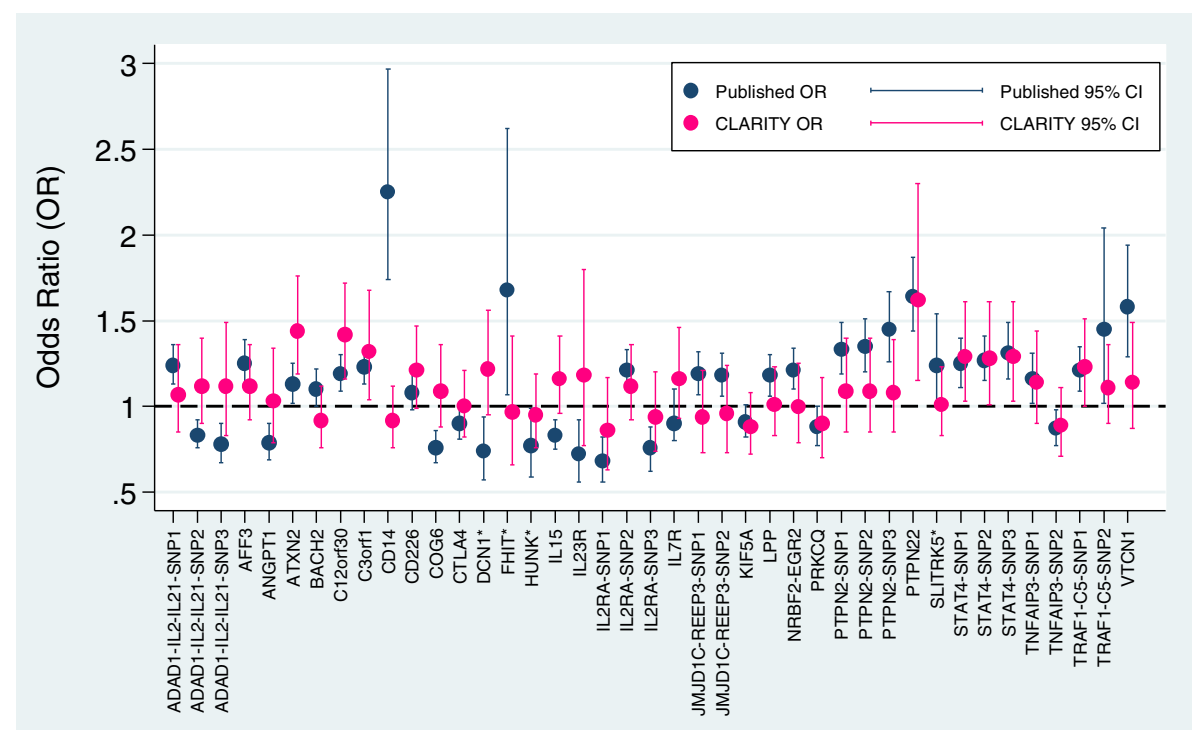

Figure 1 Forest Plot comparing previously published odds ratios (ORs) with CLARITY ORs for genes examined via nearby SNPs. Where more than one previously published OR was identified for a SNP, the OR based on the largest sample size was used. Some examined genes were excluded from this figure (see text for explanation). For genes with multiple SNPs (eg ADAD1-IL2-IL21) the SNPs are presented in the same order as listed in Table 1. * No gene attribution in original publication, closest gene by UCSC Genome Browser listed. 
Outcomes of the association analyses in CLARITY cases and controls, including $\mathrm{p}$ values for the most highly significant test and allelic test for all SNPs analysed is shown in Table 1. Figure 1 shows a forest plot of the allelic odds ratios generated in the CLARITY sample compared to previously published odds ratios (ORs) for the majority of SNPs tested. Some SNPs were not included in this figure, including SNPs for which an OR was not presented in the original report, or where SNPs were previously associated specifically with rarer JIA subtypes. Our data demonstrates clear evidence of replication (defined as $\mathrm{p}<0.05$ for any test, ORs or case-control allele frequency differences in a direction consistent with previous reports) for SNPs at loci containing the genes ATXN2, c12orf30, c3orf1, PTPN22, STAT4, and TRAF1-C5. Possible evidence of replication (defined as $\mathrm{p}<0.2$ for any test, ORs or case-control allele frequency differences in a direction consistent with previous reports) was also generated for SNPs near AFF3, CD226, MBL2, PSTPIP1, and RANTES (CCL5). For IL15, we found a significant association, but in the opposite direction to that previously reported. The IL15 SNP is an A/T transversion with frequencies of both alleles close to $50 \%$, and thus there is the possibility of allele reversal. Although our minor $\mathrm{T}$ allele frequency in controls was entirely consistent with that found in the prior study, it is difficult to be sure that the IL15 assays used in both studies were based on the same DNA strand. We therefore cannot be sure if our data supports replication. Additionally for CTLA4, considered a general autoimmunity susceptibility gene but with conflicting association results for JIA [5,24], we did not generate any evidence of replication.

We then performed a sensitivity analysis in which we included only cases $(n=200)$ and controls $(n=341)$ of European ancestry using the stringent definition of selfreported European ancestry of all four of the child's grandparents. Non-European participants, along with participants for whom full grandparent data was not provided, were excluded. The outcome of this re-analysis is shown in Additional file 1: Table S1 and Additional file 1: Figure S1. In general, the results of this European-only analysis were not materially different to the full sample analysis (taking into account reduced statistical power resulting from a reduction of sample size), with one exception. ATXN2 appeared influenced by ethnicity, with an opposite, non-significant, direction of effect in the European subgroup.

In conclusion, we have provided independent replication data for JIA susceptibility loci that have previously been identified using a generally limited number of international sample collections. We have confirmed association of JIA with SNPs close-by to c12orf30, c3orf1, PTPN22, STAT4, and TRAF1-C5; and we have provided further support for the association of SNPs close-by to
AFF3, CD226, MBL2, PSTPIP1, and CCL5. A limitation of our study was our relatively small sample size; our full dataset had $80 \%$ power to detect an OR of 1.4 for an allele at $20 \%$ frequency in the population at an alpha of 0.05 . Given that many of the published ORs were less than 1.4, and that a number of the SNPs analysed had minor allele frequencies less than $20 \%$, we cannot, from our current data, exclude association of any of the SNPs examined. Our current sample size also precluded detailed subtype-specific association analyses. Large collaborative GWAS efforts would be beneficial in confirming the outstanding genes, and providing further novel insights into the breadth of genetic loci involved in JIA susceptibility.

\section{Additional file}

Additional file 1: Data pertaining to SNPs removed from analysis during QC, and re-analysis of SNP association restricted to those of confirmed European descent.

\section{Competing interests}

The authors declare that they have no competing interests.

\section{Authors' contributions}

JE and JM conceived, designed and led the study. RC performed the SNP genotyping. AP managed the study data. ALP advised and assisted with study design and collection of epidemiological data. RA and JA assisted with case study design, and JM, RA and JA assisted with recruitment through their paediatric rheumatology clinics. JE wrote the manuscript, and all authors participated in drafting the manuscript to the final version. All authors read and approved the final manuscript.

\section{Acknowledgements}

We gratefully thank the families who kindly participated in this study. We thank Betty Lim and Sarah Macnee for their involvement in the initiation of the study and recruitment of participants, Amanda Hawker and William Siero for assistance with control recruitment and data entry, and Susan MatthyzRosa for assistance with data entry. We acknowledge support from the National Health and Medical Research Council of Australia, Arthritis Australia, Rebecca L Cooper Foundation, LEW Carty Charitable Fund, ANZ Medical Research and Technologies in Victoria Fund, Equity Trustees Lynne Quayle Charitable Trust Fund, The Australian Academy of Science, and The Victorian State Government Operational Infrastructure Support Program. JE was supported by a National Health and Medical Research Council of Australia Capacity Building Grant in Population Health, and an Australian Research Council Future Fellowship.

\section{Author details}

'Genes, Environment \& Complex Disease, Murdoch Childrens Research Institute, 50 Flemington Rd, Parkville, Vic 3052, Australia. ${ }^{2}$ Environmental \& Genetic Epidemiology Research, Murdoch Childrens Research Institute, Parkville, Vic 3052, Australia. ${ }^{3}$ Arthritis \& Rheumatology, Murdoch Childrens Research Institute, Parkville, Vic 3052, Australia. ${ }^{4}$ Rheumatology Unit, Department of General Medicine, Royal Children's Hospital, Parkville, Vic 3052, Australia.

Received: 15 November 2012 Accepted: 11 March 2013 Published: 18 March 2013

\section{References}

1. Hollenbach JA, Thompson SD, Bugawan TL, Ryan M, Sudman M, Marion M, Langefeld CD, Thomson G, Erlich HA, Glass DN: Juvenile idiopathic arthritis and HLA class I and class II interactions and age-at-onset effects. Arthritis Rheum 2010, 62:1781-1791. 
2. Hinks A, Cobb J, Sudman M, Eyre S, Martin P, Flynn E, Packham J, Barton A, Worthington J, Langefeld CD, et al: Investigation of rheumatoid arthritis susceptibility loci in juvenile idiopathic arthritis confirms high degree of overlap. Ann Rheum Dis 2012, 71:1117-1121.

3. Ellis JA, Ponsonby AL, Pezic A, Chavez RA, Allen RC, Akikusa JD, Munro JE: CLARITY: ChiLdhood Arthritis Risk factor Identification sTudY. Pediatr Rheumatol 2012, 10:37.

4. Albers HM, Kurreeman FA, Stoeken-Rijsbergen G, Brinkman DM, Kamphuis SS, van Rossum MA, Girschick HJ, Wouters C, Saurenmann RK, Hoppenreijs $E$, et al: Association of the autoimmunity locus $4 q 27$ with juvenile idiopathic arthritis. Arthritis Rheum 2009, 60:901-904.

5. Hinks A, Eyre S, Ke X, Barton A, Martin P, Flynn E, Packham J, Worthington J, Thomson W: Association of the AFF3 gene and IL2/IL21 gene region with juvenile idiopathic arthritis. Genes Immun 2010, 11:194-198.

6. Thompson SD, Sudman M, Ramos PS, Marion MC, Ryan M, Tsoras M, Weiler T, Wagner M, Keddache M, Haas JP, et al: The susceptibility loci juvenile idiopathic arthritis shares with other autoimmune diseases extend to PTPN2, COG6, and ANGPT1. Arthritis Rheum 2010, 62:3265-3276.

7. Hinks A, Martin P, Flynn E, Eyre S, Packham J, Barton A, Worthington J, Thomson W: Investigation of type 1 diabetes and coeliac disease susceptibility loci for association with juvenile idiopathic arthritis. Ann Rheum Dis 2010, 69:2169-2172.

8. Prahalad S, Hansen S, Whiting A, Guthery SL, Clifford B, McNally B, Zeft AS, Bohnsack JF, Jorde LB: Variants in TNFAIP3, STAT4, and C12orf30 loci associated with multiple autoimmune diseases are also associated with juvenile idiopathic arthritis. Arthritis Rheum 2009, 60:2124-2130.

9. Thompson SD, Marion MC, Sudman M, Ryan M, Tsoras M, Howard TD, Barnes MG, Ramos PS, Thomson W, Hinks A, et al: Genome-wide association analysis of juvenile idiopathic arthritis identifies a new susceptibility locus at chromosomal region 3q13. Arthritis Rheum 2012, 64:2781-2791.

10. Hinks A, Martin P, Flynn E, Eyre S, Packham J, Barton A, Worthington J, Thomson W: Association of the CCR5 gene with juvenile idiopathic arthritis. Genes Immun 2010, 11:584-589.

11. Zeng HS, Chen XY, Luo XP: The association with the $-159 \mathrm{C} / \mathrm{T}$ polymorphism in the promoter region of the CD14 gene and juvenile idiopathic arthritis in a Chinese Han population. J Rheumatol 2009, 36:2025-2028.

12. Skinningsrud B, Lie BA, Husebye ES, Kvien TK, Forre O, Flato B, Stormyr A, Joner G, Njolstad PR, Egeland T, Undlien DE: A CLEC16A variant confers risk for juvenile idiopathic arthritis and anti-cyclic citrullinated peptide antibody negative rheumatoid arthritis. Ann Rheum Dis 2010, 69:1471-1474

13. Hinks A, Martin P, Flynn E, Eyre S, Packham J, Barton A, Worthington J, Thomson W: Subtype specific genetic associations for juvenile idiopathic arthritis: ERAP1 with the enthesitis related arthritis subtype and IL23R with juvenile psoriatic arthritis. Arthritis Res Ther 2011, 13:R12.

14. Hinks A, Ke X, Barton A, Eyre S, Bowes J, Worthington J, Thompson SD, Langefeld CD, Glass DN, Thomson W: Association of the IL2RA/CD25 gene with juvenile idiopathic arthritis. Arthritis Rheum 2009, 60:251-257.

15. Hinks A, Eyre S, Ke X, Barton A, Martin P, Flynn E, Packham J, Worthington J, Thomson W: Overlap of disease susceptibility loci for rheumatoid arthritis and juvenile idiopathic arthritis. Ann Rheum Dis 2010, 69:1049-1053.

16. Gergely P Jr, Pazar B, Nagy ZB, Gombos T, Rajczy K, Balogh Z, Orban I, Sevcic K, Poor G: Structural polymorphisms in the mannose-binding lectin gene are associated with juvenile idiopathic arthritis. J Rheumatol 2009, 36:843-847.

17. Day TG, Ramanan AV, Hinks A, Lamb R, Packham J, Wise C, Punaro M, Donn RP: Autoinflammatory genes and susceptibility to psoriatic juvenile idiopathic arthritis. Arthritis Rheum 2008, 58:2142-2146.

18. Hinks A, Barton A, John S, Bruce I, Hawkins C, Griffiths CE, Donn R, Thomson W, Silman A, Worthington J: Association between the PTPN22 gene and rheumatoid arthritis and juvenile idiopathic arthritis in a UK population: further support that PTPN22 is an autoimmunity gene. Arthritis Rheum 2005, 52:1694-1699.

19. Yao TC, Tsai YC, Huang JL: Association of RANTES promoter polymorphism with juvenile rheumatoid arthritis. Arthritis Rheum 2009, 60:1173-1178.

20. Jimenez-Morales S, Velazquez-Cruz R, Ramirez-Bello J, Bonilla-Gonzalez E, Romero-Hidalgo S, Escamilla-Guerrero G, Cuevas F, Espinosa-Rosales F, Martinez-Aguilar NE, Gomez-Vera J, et al: Tumor necrosis factor-alpha is a common genetic risk factor for asthma, juvenile rheumatoid arthritis, and systemic lupus erythematosus in a Mexican pediatric population. Hum Immunol 2009, 70:251-256.

21. Behrens EM, Finkel TH, Bradfield JP, Kim CE, Linton L, Casalunovo T, Frackelton EC, Santa E, Otieno FG, Glessner JT, et al: Association of the TRAF1-C5 locus on chromosome 9 with juvenile idiopathic arthritis. Arthritis Rheum 2008, 58:2206-2207.

22. Hinks A, Barton A, Shephard N, Eyre S, Bowes J, Cargill M, Wang E, Ke X, Kennedy GC, John S, et al: Identification of a novel susceptibility locus for juvenile idiopathic arthritis by genome-wide association analysis. Arthritis Rheum 2009, 60:258-263.

23. Purcell S, Neale B, Todd-Brown K, Thomas L, Ferreira MA, Bender D, Maller J, Sklar P, de Bakker PI, Daly MJ, Sham PC: PLINK: a tool set for wholegenome association and population-based linkage analyses. Am J Hum Genet 2007, 81:559-575.

24. Prahalad S, Bohnsack JF, Whiting A, Clifford B, Jorde LB, Guthery SL, Thompson SD, Glass DN, Bamshad MJ: Lack of association of functional CTLA4 polymorphisms with juvenile idiopathic arthritis. Arthritis Rheum 2008, 58:2147-2152.

doi:10.1186/1546-0096-11-12

Cite this article as: Ellis et al:: Independent replication analysis of genetic loci with previous evidence of association with juvenile idiopathic arthritis. Pediatric Rheumatology 2013 11:12.

\section{Submit your next manuscript to BioMed Central and take full advantage of:}

- Convenient online submission

- Thorough peer review

- No space constraints or color figure charges

- Immediate publication on acceptance

- Inclusion in PubMed, CAS, Scopus and Google Scholar

- Research which is freely available for redistribution

Submit your manuscript at www.biomedcentral.com/submit
C Biomed Central 